Georgia State University

ScholarWorks @ Georgia State University

2015

\title{
The Robustness of Honesty Effects on Budget Proposals when the Superior has Rejection Authority
}

Jeremy Douthit

University of Arizona, jdouthit2@email.arizona.edu

Douglas E. Stevens

Georgia State University, dstevens11@gsu.edu

Follow this and additional works at: https://scholarworks.gsu.edu/accountancy_facpub

Part of the Accounting Commons

\section{Recommended Citation}

Douthit J, Stevens D. The Robustness of Honesty Effects on Budget Proposals when the Superior has Rejection Authority. The Accounting Review. March 2015;90(2):467-493.

This Article is brought to you for free and open access by the School of Accountancy at ScholarWorks @ Georgia State University. It has been accepted for inclusion in Accountancy Faculty Publications by an authorized administrator of ScholarWorks @ Georgia State University. For more information, please contact scholarworks@gsu.edu. 


\title{
The Robustness of Honesty Effects on Budget Proposals when the Superior has Rejection Authority
}

\author{
Jeremy D. Douthit \\ The University of Arizona \\ Douglas E. Stevens \\ Georgia State University
}

\begin{abstract}
Rankin, Schwartz, and Young (2008) find experimental evidence that manipulating whether the budget request of the subordinate requires a factual assertion has no effect on budgetary slack when the superior can reject the budget. This calls into question the role of honesty in participative budgeting settings. Using Rankin et al.'s (2008) manipulation to capture honesty effects, we examine the robustness of honesty effects on budget proposals when the superior has rejection authority in two experiments. In Experiment 1, we document that honesty has a strong effect on budgetary slack when the salience of distributional fairness is reduced by withholding the relative pay of the superior from the subordinate. In Experiment 2, we document that honesty continues to have a strong effect on budgetary slack when the salience of reciprocity is increased by giving the superior the ability to set the subordinate's salary. Thus, our evidence suggests that honesty effects on budget proposals are generally robust to giving the superior rejection authority. Our study helps explain prior experimental results and clarifies the role of honesty in participative budgeting settings.
\end{abstract}

Keywords: budgetary slack; honesty; distributional fairness; reciprocity.

Data Availability: Experimental data are available from the authors upon request.

This paper benefitted from many helpful suggestions from John Harry Evans III (senior editor), Donald V. Moser (editor), and two anonymous reviewers. We also acknowledge the helpful comments of Hank Alewine, Orie Barron, Bruce Billings, Allen Blay, Alisa Brink, Kimball Chapman, Kevin Eller, Sukari Farrington, Bachman Fulmer, John Hamman, Steve Huddart, Mark Isaac, Steve Kachelmeier, Gregory McPhee, Rick Morton, Doug Norton, Hong Qu, Bill Rankin, Kenny Reynolds, Steve Salterio, Ivo Tafkov, Michael Williamson, Rick Young, and workshop participants at the Florida State University Accounting Research Colloquium, the Florida State University Experimental Economics Group, the Georgia State University Accounting Workshop, the Pennsylvania State University Accounting Research Colloquium, the 2012 ABO Midyear Meeting, the 2013 MAS Midyear Meeting, the 2013 GMAR Symposium, and the 2013 AAA Annual Meeting. This research was funded by a research grant from the Institute of Management Accountants' (IMA) Foundation for Applied Research, and we received many helpful comments from the directors of the IMA Foundation. Finally, we thank Phil Brookins for his programming and experimental assistance.

Editor's note: Accepted by Donald V. Moser. 


\section{INTRODUCTION}

$\mathrm{P}$ articipative budgeting represents one of the most widely researched topics of experimental research in managerial accounting (Brown, Evans, and Moser 2009). This body of research is important because participative budgeting is commonly used to aid in the efficient allocation of resources in decentralized firms (J. Shields and M. Shields 1998; Libby and Lindsay 2007). To the extent that subordinates truthfully communicate their private information in the budget, participative budgeting yields useful information for central management to use in production, marketing, and capital budgeting decisions (Evans, Hannan, Krishnan, and Moser 2001). Traditional agency theory, however, assumes that subordinates suffer no disutility for misrepresenting their private information and will build slack into their budget to maximize their wealth, absent a contractual incentive to do otherwise (Baiman 1990). From this perspective, budgetary slack is a type of opportunistic behavior that reduces the value of participative budgeting to the firm (Baiman and Evans 1983; Merchant 1985; Kren and Liao 1988). ${ }^{1}$

Contrary to the assumptions of traditional agency theory, prior experimental studies of participative budgeting find that subordinates exhibit honesty concerns in their budget proposals (Young 1985; Chow, Cooper, and Waller 1988; Evans et al. 2001; Stevens 2002; Hannan, Rankin, and Towry 2006; Zhang 2008). ${ }^{2}$ These studies also find that such honesty concerns can lead to increased efficiency for the firm in participative budgeting settings (Evans et al. 2001). ${ }^{3}$ This suggests that honesty may support the underlying value of participative budgeting to the firm. However, surveys of managers and accountants reflect continuing concerns that subordinates may strategically manipulate the budgeting process to the detriment of the firm (Neely, Sutcliff, and Heyns 2001; Libby and Lindsay 2007). Jensen (2001, 96) characterizes participative budgeting as a game that "encourages managers to lie and cheat." This view, however, does not explain the continued popularity of participative budgeting as an organizational control (Shields and Shields 1998; Libby and Lindsay 2010).

Recent experimental evidence in Rankin, Schwartz, and Young (2008; hereafter, RSY) calls into question the role of honesty in participative budgeting settings. RSY note that previous experimental studies finding evidence for honesty use budgetary slack as a direct measure of honesty and grant the subordinate unilateral budget authority. They argue that budgetary slack is influenced by other non-pecuniary preferences besides honesty, such as preferences for the distribution of wealth, and that granting unilateral budget authority may cause the subordinate to frame the budgeting setting as an ethical dilemma. RSY contribute to the literature by attempting to isolate the incremental effect of honesty on budgetary slack and by examining budgeting settings where the superior can reject the subordinate's budget. RSY's experimental design isolates the incremental effect of honesty by manipulating the mode of communication of the budget proposal, such that subordinates either provide a factual assertion of actual project cost or propose a division of the project earnings without a factual assertion. RSY find less budgetary slack when the budget communication requires a factual assertion in the setting where the subordinate has unilateral

1 The literature frequently distinguishes between budgetary slack and organizational slack. Budgetary slack occurs when expense budgets are overstated or when revenue or production budgets are understated due to managers' incentives to outperform the budget, thereby leading to inefficiencies for the firm (Kren and Liao 1988). Organizational slack can be viewed positively as a response to uncertainty that provides a stabilizing influence in down times due to the availability of margin (Cyert and March 1963; Merchant 1985).

2 Prior experimental studies use the honesty construct to explain the tendency of a person to make true statements despite incentives to make false statements (Evans et al. 2001; Rankin et al. 2008). Consistent with economic models that incorporate honesty in a capital budgeting setting, we define honesty as a preference that causes disutility from making false statements (Mittendorf 2006).

3 It may not be honesty per se that motivates honest behavior, but simply the desire to be perceived as honest (Hannan et al. 2006). As with prior studies, we do not distinguish between these two motivations in our study. 
authority, but not when the superior has rejection authority. Exit questionnaire data suggest that their result is due to subordinates framing the setting where the superior has rejection authority as a strategic negotiation rather than an ethical dilemma.

Because participative budgeting settings in practice typically include superior rejection authority, it is important to examine the robustness of honesty effects on budget proposals in this enhanced setting. RSY $(2008,1085)$ conclude that their results are consistent with extrinsic control in the form of superior rejection authority "crowding out" intrinsic motivation to display honesty in the budget. This is consistent with recent social norm theory suggesting that situational cues play an important role in activating social norms and determining which norm will dominate in the presence of conflicting norms (Bicchieri 2006). We identify three social norms that may be activated and affect budgetary slack in a participative budgeting setting where the superior has rejection authority: honesty, distributional fairness, and reciprocity. Consistent with economic models incorporating honesty in a capital budgeting setting, we define honesty as a preference that causes disutility from making false statements (Mittendorf 2006). Consistent with economic models incorporating social preferences in game theory, we define distributional fairness as a preference over the relative distribution of outcomes that causes disutility from inappropriate allocations of an available surplus (Fehr and Schmidt 1999; Falk, Fehr, and Fischbacher 2003) and reciprocity as a preference that causes positive utility from repaying kind actions with kindness and unkind actions with unkindness (Rabin 1993; Cox and Deck 2005). To examine the robustness of honesty effects on budget proposals when the superior has rejection authority, we manipulate the salience of distributional fairness and reciprocity norms in two experiments.

In Experiment 1, we examine the effect of distributional fairness on honesty effects by manipulating the ability of the subordinate to discern the level of pay the superior receives relative to the subordinate's level of pay. In typical budgeting settings, the relative distribution of outcomes from a given project and budget decision is less transparent than in laboratory settings. This transparency is an important factor to consider, since the participative budgeting setting is economically equivalent to an ultimatum game when the superior has rejection authority (RSY 2008), and experimental studies of ultimatum games document that distributional fairness becomes salient when relative pay information is transparent (Croson 1996; Guth, Huck, and Muller 2001; Charness and Gneezy 2008). When relative outcomes are not transparent, however, the salience of distributional fairness is reduced (Dana, Weber, and Kuang 2007). Recent social norm theory (Bicchieri 2006, 131) suggests that situational cues determine which norm is most salient and will dominate behavior in the presence of conflicting norms. Thus, while RSY manipulated the salience of honesty by manipulating the form of the budget communication, the transparency of relative pay in their study may have made distributional fairness more salient than honesty. Experiment 1 addresses this research question by testing the robustness of honesty effects under superior rejection authority where the salience of distributional fairness is manipulated.

In Experiment 2, we examine the effect of reciprocity on honesty effects by manipulating the ability of the superior to set the subordinate's pay while reducing the salience of distributional fairness, as in Experiment 1. While superiors typically play a role in setting the subordinate's pay in practice, researchers have only recently examined this important aspect of participative budgeting. Using a group setting where the superior sets the salary of two subordinates, Zhang (2008) finds evidence of reciprocity in that subordinates build less slack into their budget when the superior offers higher pay. However, as with most studies in the literature, Zhang (2008) uses budgetary slack as a direct measure of honesty and does not give superiors rejection authority. ${ }^{4}$ Thus, while

\footnotetext{
${ }^{4}$ Other ways in which our study is distinguishable from Zhang (2008) are that she investigates a multi-agent setting and focuses on the role of wage levels and inter-agent communication on budgetary slack and whistleblowing.
} 
her study documents that reciprocity affects budgetary slack, it remains to be determined whether honesty affects budgetary slack under superior rejection authority in a budgeting setting where reciprocity is salient. Experiment 2 addresses this research question by testing the robustness of honesty effects under superior rejection authority where the salience of reciprocity is manipulated.

In both experiments, we utilize a slightly modified version of RSY's experimental setting where the superior has rejection authority. ${ }^{5}$ Following the strategic budgeting setting in Schatzberg and Stevens (2008), we pay the subordinate's fixed salary from the superior's endowment rather than from the experimenter, as in RSY. This design choice is likely to capture an important aspect of budgeting settings where the resources of the firm are limited and the superior is thereby motivated to be efficient with those resources. As in RSY, we capture the incremental effect of honesty on budgetary slack as the difference between a budget proposal that requires a factual assertion about the cost of the project and a budget proposal that simply offers the superior a portion of the profit from the project without a factual assertion.

In Experiment 1, we document an interaction between distributional fairness and honesty whereby the incremental effect of honesty on budgetary slack is stronger when the salience of distributional fairness is reduced by keeping the level of pay the superior receives relative to the subordinate private and known only by the superior. When the superior's relative pay is private, honesty has a strong incremental effect on budgetary slack. When the superior's relative pay is common knowledge, as in RSY, honesty still has a marginally significant effect on budgetary slack. Thus, distributional fairness significantly weakens, but does not completely dominate, honesty in our experimental setting. In Experiment 2, we document that honesty effects on budgetary slack are robust to the salience of reciprocity. When the superior has the authority to set the subordinate's salary, subordinates create less budgetary slack when the superior offers a higher salary, as in Zhang (2008). Nevertheless, honesty continues to have a strong incremental effect on budgetary slack in this experimental setting.

Giving the superior rejection authority and the authority to set the subordinate's salary in Experiment 2 allows us to examine how honesty and reciprocity norms affect the rejection and salary behavior of the superior. We find that, after controlling for the reported budget level, the probability of rejection is higher when the budget communication requires a factual assertion, consistent with superiors being motivated to enforce honesty even at a cost to themselves (Hannan, Rankin, and Towry 2010). Further, the probability of rejection is higher when the superior sets a higher salary, consistent with superiors being motivated to enforce reciprocity even at a cost to themselves. Finally, we find that reciprocity alone is insufficient to control the subordinate's opportunism. While subordinates claim less slack as their pay increases, the decrease in slack does not completely offset the cost of the increased pay for the superior. Thus, even in the likely setting where the superior influences the subordinate's pay and reciprocity is present, honesty plays an important role in maintaining the efficiency of participative budgeting.

In summary, our evidence suggests that honesty effects on budget proposals are generally robust to giving the superior rejection authority. Our study helps explain prior experimental results in participative budgeting. For example, results from Experiment 1 suggest that RSY's experimental result that honesty does not have an incremental effect on budgetary slack under superior rejection authority may be partially attributable to the salience of distributional fairness in their study. While we document that distributional fairness can diminish honesty effects in experimental budgeting settings, we do not expect distributional fairness to be especially salient in budgeting settings in practice because the superior's relative pay is typically not transparent to the

\footnotetext{
${ }^{5}$ We contacted one of the RSY (2008) authors and requested their original set of instructions. Their gracious willingness to provide us their instructions allowed us to closely replicate their experimental setting aside from the changes noted.
} 
subordinate. It is more likely that reciprocity will be salient because the superior typically plays a role in setting the subordinate's pay. Results from Experiment 2 suggest that reciprocity does not diminish honesty effects and superiors can achieve higher profits by relying on such honesty. Thus, our results support prior experimental research documenting the importance of honesty in maintaining the efficiency of participative budgeting (Brown et al. 2009).

Our study also provides useful evidence for accounting theory and practice. Theorists in management accounting have traditionally used agency theory and the "nexus of contracts" view of the firm made popular in finance (Jensen and Meckling 1976). While this view of the firm has generated valuable insights and useful streams of research in accounting (Baiman 1990), it has not always been able to describe management practices and controls found in practice (Stevens and Thevaranjan 2010). Despite the potential for participative budgeting to enhance information sharing, planning, and control, some agency theorists have minimized the value of participative budgeting due to the powerful incentive to misreport private information for personal gain (Jensen 2001). Our results help explain why firms have historically used participative budgeting for both performance evaluation and control purposes despite the incentive for misreporting (Shields and Shields 1998; Libby and Lindsay 2010). Our study also suggests that the value of participative budgeting to the firm could be enhanced by incorporating contextual cues and behavioral expectations that motivate honest reporting of private information in the budget.

Next, in Section II, we present the theoretical foundation of our study. In Section III, we develop our hypotheses for Experiment 1, describe our experimental design, and present our results. In Section IV, we develop our hypotheses for Experiment 2, describe our experimental design, and present our results. In Section V, we conclude.

\section{THEORETICAL FOUNDATION}

For the theoretical foundation of our study, we utilize the agency model of participative budgeting in Antle and Eppen (1985) and incorporate insights from a model of social norm activation in Bicchieri (2006). Antle and Eppen's (1985) agency model is commonly used by experimental researchers to examine the effect of honesty in participative budgeting. In their model, there is an investment project that is being considered by a firm. Both the subordinate and the superior know the revenues that will result from the project if it is undertaken and the probability distribution of the project's cost. However, only the subordinate learns the actual cost of the project. Upon learning the actual cost of the project, the subordinate submits a cost budget proposal to the superior. The superior then decides whether to fund the project. If the project is funded, then the superior receives the profit above the cost budget and the subordinate receives the slack between the cost budget and actual cost. Absent some financial incentive or hurdle contract, the agency prediction is for the subordinate to submit the highest cost budget possible, regardless of the actual cost, and for the superior to accept any project that has a positive profit. These strong predictions are due to the traditional agency theory assumption that the subordinate and superior are motivated solely by their own wealth and leisure.

There are several features of the theoretical setting in Antle and Eppen (1985) that make it ideal for testing the effect of honesty on the budget proposals of subordinates. First, the model provides a strong agency prediction that can be used to test alternative theories of behavior (Brown et al. 2009). Second, the subordinate knows the actual cost with certainty when he proposes his budget, which controls for risk preferences (RSY 2008). Third, social pressure, reputation, and other multi-period effects that have been shown to affect budgetary slack (Young 1985; Stevens 2002) are controlled because the model is a single-period model and the superior never learns the true cost of the project.

We supplement Antle and Eppen's (1985) agency model with insights from Bicchieri's (2006) model of social norm activation. Researchers in accounting have begun to reference Bicchieri's 
(2006) model to predict how and when environmental cues activate social norms that affect the behavior of the principal and the agent (Douthit, Kearney, and Stevens 2012; Davidson and Stevens 2013). ${ }^{6}$ A social norm is a behavioral rule that may become salient and affect behavior in a given social setting. Bicchieri (2006) argues that people have conditional preferences for conforming to social norms. In her model, a social norm is activated and followed when one becomes aware that a given norm is relevant to the current setting, and a combination of empirical and normative expectations gives one a sufficient reason to follow the norm. Empirical expectations are based on the belief that a sufficiently large subset of people conforms to the norm in similar settings. Normative expectations are based on the belief that a sufficiently large subset of people expects conformance to the norm in similar settings and may be willing to sanction behavior inconsistent with the norm. Therefore, a given social norm is activated when situational cues make the norm salient and the norm shapes empirical and normative expectations of behavior. ${ }^{7}$

Bicchieri's $(2006,131)$ model predicts that in the common setting where multiple social norms are present, situational cues play an important role in determining which norm will be most salient and influence behavior. One of the most prominent social norms in society is honesty (Murphy 1993). Bicchieri's (2006) model suggests that the mode of budget communication manipulation used by RSY makes the honesty norm salient and, therefore, is a valid measure of the effect of honesty on budgetary slack. Besides honesty, we identify two other social norms that may be activated in a participative budgeting setting where the superior has rejection authority: distributional fairness and reciprocity. Below, we incorporate insights from Bicchieri's (2006) model of social norm activation to Antle and Eppen's (1985) agency model to predict how and when situational cues in the budgeting setting make distributional fairness and reciprocity norms salient and their differential effect on honesty in a participative budgeting setting.

\section{EXPERIMENT 1: HONESTY AND DISTRIBUTIONAL FAIRNESS}

\section{Hypothesis Development for Experiment 1}

In Experiment 1, we examine the robustness of honesty effects on budget proposals when the superior has rejection authority by manipulating the salience of distributional fairness. When the superior has rejection authority, the budgeting setting resembles an ultimatum game where a proposer offers a split of a surplus to a responder and the responder can either accept or reject the split (RSY 2008, 1088). If the responder rejects the offer, then neither party receives any pay. Guth, Schmittberger, and Schwarze (1982) developed the ultimatum game to test predictions of game theory and examine preferences for distributional fairness (Camerer 2003; Smith 2010). Experimental tests of the ultimatum game find that when relative payoff information is transparent, distributional fairness affects the behavior of both the proposer and responder. In contrast to the traditional game theory prediction that the proposer will offer the minimal share of the surplus and it will be accepted by the responder, proposers commonly offer 30-50 percent of the surplus and responders commonly reject offers below 20 percent (Croson 1996; Hoffman, McCabe, and Smith 2000; Guth et al. 2001; Charness and Gneezy 2008; Stanca 2010). ${ }^{8}$

\footnotetext{
${ }^{6}$ For a formal presentation of Bicchieri's (2006) model and a detailed discussion of its usefulness to experimental research in accounting, see Davidson and Stevens (2013).

7 While empirical expectations aid in social norm activation, it is possible for normative expectations alone to activate a social norm, provided an individual recognizes this expectation as legitimate in and of itself (Bicchieri 2008). Also, normative expectations may induce conformance to the social norm without the threat of sanctions (Bicchieri 2006).

8 The game theoretic prediction is based on the traditional agency assumption that participants are motivated solely by their own wealth and leisure. For reviews of the literature, see Guth (1995) and Cooper and Kagel (2015).
} 
In the traditional ultimatum game, the surplus that the proposer splits with the responder is an endowment or monetary gift from the experimenter that is common knowledge to both parties. The default expectation generated by distributional fairness in this setting is an equal-split norm (Bicchieri 2006). In asking herself what the responder would accept, the proposer is forced to look at the cues in the decision setting and conclude that there is an expected opportunity cost of not following the equal-split norm. However, changes in the decision setting have been found to alter distributional fairness expectations in both the proposer and the responder. Responders are willing to accept lower offers from the proposer when such offers are generated by a random device or the choice of the proposer is otherwise constrained (Blount 1995). Research also suggests that distributional fairness is defined in a self-serving manner, as proposers offer lower shares of the surplus when they possess advantageous private information that makes such offers appear fair to the responder (Kagel, Kim, and Moser 1996). Finally, research shows that proposers are willing to restrict their information to avoid having to consider the distributional fairness of their offer (Dana et al. 2007).

In summary, research suggests that the transparency of relative payoffs is a powerful situational cue that makes distributional fairness salient in settings that resemble an ultimatum game. In participative budgeting settings in practice, subordinates are typically unaware of the pay of their superiors or how a given project and budget influences this pay. Thus, distributional fairness is unlikely to be as salient in budgeting settings in practice as in experimental budgeting settings where relative pay is transparent. Experimental studies in economics (Carpenter 2002; Dana et al. 2007) and accounting (Kachelmeier and Towry 2002; Davidson and Stevens 2013) reduce the salience of distributional fairness by keeping relative pay information hidden from participants. Therefore, we manipulate the salience of distributional fairness by disclosing or withholding information about the relative pay of the superior. In one condition, the superior's initial endowment is common knowledge to both parties, and in the other condition, the superior's initial endowment is known only by the superior.

We argue that honesty and distributional fairness represent conflicting social norms in a participative budgeting setting. Prior experimental evidence suggests that individuals use dishonest actions to both help and harm others in order to create more equitable outcomes (Gino and Pierce 2010). This offsetting relation between honesty and distributional fairness is likely to be present in an experimental budgeting setting because the subordinate affects the distribution of the project surplus through the honesty of his budget report (RSY 2008, 1084). To the extent that honest reporting leads to inequitable outcomes, equitable outcomes can only be achieved through dishonest reporting. That is, an honest report gives the entirety of the production surplus to the superior, and the only avenue available for the subordinate to receive an equitable share of the production surplus is to report dishonestly. This is often the case with experimental budgeting settings, such as RSY.

Bicchieri's (2006, 131) model predicts that where conflicting social norms are present, expectations and behavior will be affected by the most salient of the social norms. In experimental budgeting settings, this suggests that participants must assess a probability distribution over the range of possible social norms that will be activated. As situational cues make distributional fairness more salient, it increases the probability that this social norm will be activated and dominate honesty. Consistent with ultimatum game results, we expect the disclosure of relative payoff information to be a powerful situational cue that makes distributional fairness salient in an experimental budgeting setting. Thus, we manipulate the salience of distributional fairness by manipulating the transparency of relative pay information to the subordinate, and we expect honesty effects on budgetary slack to be diminished when relative pay information is transparent. Based on Bicchieri's (2006) model and prior experimental evidence, in H1, we predict that honesty will have 
a greater effect on budgetary slack when the relative pay of the superior is withheld from the subordinate:

H1: Honesty will have a greater effect on budgetary slack when the relative payoff of the superior is withheld from the subordinate.

\section{Experimental Design for Experiment 1}

To test our first hypothesis, we use a controlled laboratory experiment that contains key aspects of Antle and Eppen's (1985) model. Upon arriving at the laboratory, participants were randomly assigned to the role of either a superior or a subordinate. ${ }^{9}$ They retained their role for the entire experiment. The following steps took place in each period of the experiment. The experimental task involved an investment project that yielded revenue of 200 experimental dollars when funded. The cost of the investment was uniformly distributed between 0-200 experimental dollars in increments of 1 . The revenue and cost distribution of the project were common knowledge. The superior received an initial endowment of 100 experimental dollars. The subordinate received a salary of 100 experimental dollars from the superior's initial endowment ${ }^{10}$ and observed the actual cost of the project. Upon learning the actual cost, the subordinate proposed a budget to the superior. The superior then decided whether to fund the project. If the project was funded, then the subordinate received the reported cost less the actual cost (budgetary slack) and the superior received the project revenue (200 experimental dollars) less the reported cost. If the project was not funded, then neither party received any payoff from the project. However, the subordinate received a salary from the superior's endowment of funds regardless of whether the project was funded. Participants were randomly and anonymously rematched with each other after each period. There were 20 periods.

Experiment 1 uses a $2 \times 2$ factorial design where the subordinate's knowledge of the superior's initial endowment level is manipulated at two levels (Public Superior Pay versus Private Superior Pay) and the mode of budget communication is manipulated at two levels (No Factual Assertion versus Factual Assertion). This experimental design is presented in Figure 1. We manipulate the subordinate's knowledge of the superior's initial endowment to manipulate the salience of distributional fairness. The superior paid the subordinate his salary out of her initial endowment of funds, which was held constant at 100 experimental dollars in each period. In the Public Superior Pay treatment, the level of the superior's initial endowment was common knowledge, as was the requirement that all 100 experimental dollars were spent on the subordinate's salary. Similar to prior experimental budgeting studies, this treatment made relative pay between the superior and the subordinate transparent and created a budgeting setting where the salience of distributional fairness was increased. In the Private Superior Pay treatment, only the superior knew the level of her initial endowment, which was still fixed at 100 experimental dollars. It was common knowledge that the superior had to use 100 experimental dollars of her endowment to pay the subordinate's salary. Because the superior's initial endowment was known only by the superior, the subordinate could not evaluate relative pay outcomes definitely. Thus, the salience of distributional fairness was decreased in this setting.

Consistent with RSY, we manipulate the mode of budget communication to capture the incremental effect of honesty on budgetary slack. In the Factual Assertion treatment, the

\footnotetext{
9 The two roles were labeled "owner" and "manager" in the experimental instructions. For consistency, the terms superior and subordinate are used in the continued exposition.

10 The level of the superior's endowment was set to create an economically identical setting to the Superior Authority treatment in RSY, with the exception that the subordinate's salary came from the superior's endowment rather than directly from the experimenter.
} 


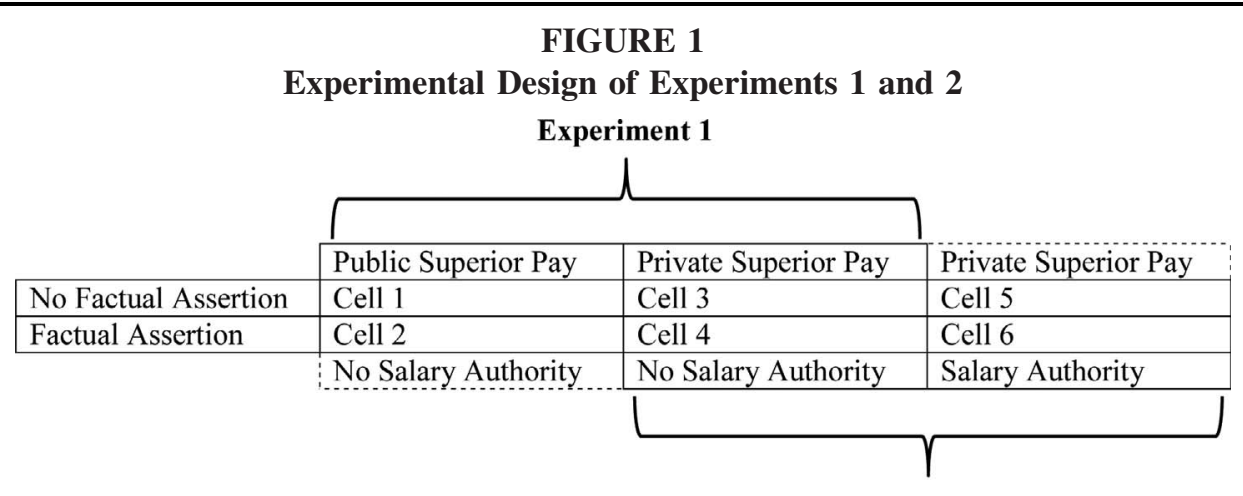

Experiment 2

Experiment 1 examines the robustness of honesty effects on budgetary slack to distributional fairness norms by manipulating whether the relative pay (initial endowment) of the superior is public or private. Experiment 2 examines the robustness of honesty effects on budgetary slack to reciprocity norms by manipulating whether the superior has the authority to set the subordinate's salary. The incremental effect of honesty on budgetary slack is measured by manipulating whether the budget communication includes a factual assertion. Both experiments utilize a $2 \times 2$ experimental design and share the same two control cells (Cells 3 and 4).

subordinate's budget required an assertion of fact regarding the project's actual cost. Since there was the possibility of making an untrue assertion or dishonest budget, this treatment created a setting where the salience of honesty was increased. In the No Factual Assertion treatment, the subordinate's budget proposed the amount of profit from the project going to the superior. Since there was no possibility of making an untrue assertion, this treatment created a budgeting setting where the salience of honesty was decreased. In both treatments, the subordinate was not allowed to achieve a negative outcome from the project (i.e., underreport actual costs or offer more than the full profit). All of our experimental treatments provide the same agency prediction (Camerer 2003). That is, the subordinate is predicted to report the highest possible cost or offer the lowest possible profit from the project and the superior is predicted to always accept the project to maximize her wealth. The timeline for Experiment 1 is presented in Figure 2.

Participants were students at a large southeastern university who interacted anonymously through a computer network using the z-Tree software package (Fischbacher 2007). Prior to the experimental sessions, a set of randomly generated cost sequences was chosen and used in all treatments. This controlled for potential order effects and ensured that random noise in the actual costs did not drive participant behavior differently between treatments. This procedure also ensured

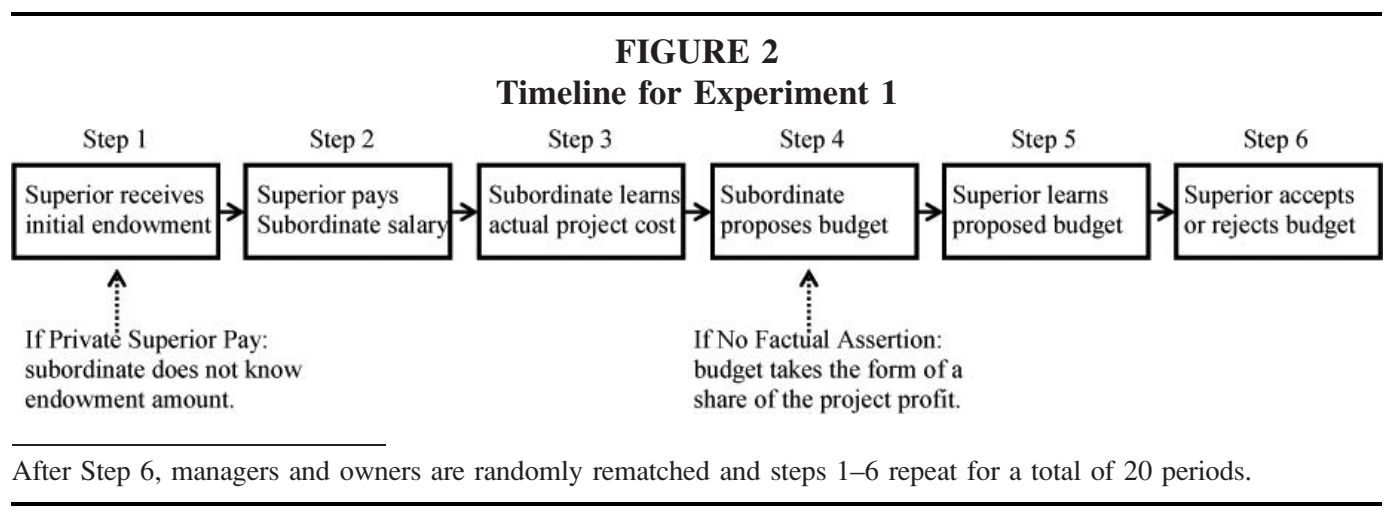


that the realized cost was equal for each period across treatments. At the end of each session, participants were paid privately in cash. Participants received a show-up fee of $\$ 10$ and earnings based upon their decisions in one randomly selected period at a rate of $\$ 1=5$ experimental dollars. ${ }^{11}$ The experiment was conducted in eight sessions, with 14 participants in half of the sessions and 16 participants in the rest of the sessions. Each session lasted about 45 minutes, and the average earnings was $\$ 20.13$, in addition to the $\$ 10$ show-up fee.

\section{Results for Experiment 1}

Participants responded to a number of statements on the exit questionnaire that were designed to test the effectiveness of our experimental manipulations and controls. Participants responded to these statements on a seven-point Likert scale $(1=$ Strongly Disagree, $7=$ Strongly Agree). Tests of manipulations and controls are the mean difference from the neutral response of 4 . In untabulated results, we find evidence that our experimental manipulations and controls were effective for Experiment 1 (all $\mathrm{p}<0.05$ ). To examine if we successfully manipulated the salience of distributional fairness, we examine responses to the exit questionnaire item, "I wanted both parties to have even payoffs." This is a measure of the subordinate's concern for the equal-split norm, which is a distributional fairness norm that frequently becomes a focal point in ultimatum games when relative pay is transparent (Fehr and Schmidt 1999; Camerer 2003; Bicchieri 2006; Andreoni and Bernheim 2009). Responses in the Private Superior Pay treatment were significantly lower for this item than those in the Public Superior Pay treatment (3.4 versus 4.7, $\mathrm{t}=4.01, \mathrm{p}<0.01$ ). Thus, our attempt to manipulate the salience of distributional fairness by withholding relative pay information from the subordinate appears to have been successful.

The descriptive statistics for Experiment 1 are presented in Table $1 .{ }^{12}$ As in prior research, we measure budgetary slack as the slack claimed over the slack available (Evans et al. 2001; RSY 2008). Since the realized cost is the same in each decision period across treatments, the total slack available over the course of the experiment is the same in each treatment and the average slack claimed by subordinates can be compared easily between treatments and over time. The average cost in each treatment is 100.4 experimental dollars. In Experiment 1, the highest level of budgetary slack occurred in the Private Superior Pay/No Factual Assertion treatment, followed by the Public Superior Pay/No Factual Assertion treatment, then the Public Superior Pay/Factual Assertion treatment, and slack was lowest in the Private Superior Pay/Factual Assertion treatment. These mean results are graphed in Figure 3.

Our first hypothesis predicts that honesty will have a greater effect on budgetary slack when the relative pay of the superior is withheld from the subordinate. To test this prediction, we estimate an ANOVA on the effect of Factual Assertion, Private Superior Pay, and the interaction of these two dummy variables on budgetary slack. ${ }^{13}$ The results of this analysis are reported in Panel A of Table 2. In the full model, we document a strong main effect on Factual Assertion $(\mathrm{F}=18.13, \mathrm{p}<0.01$,

11 Randomly rematching superior/subordinate pairs each period and paying participants for only one randomly selected period helped ensure that our experiments formed a repeating, single-period setting. This was important to control for reputation and other social effects that were not the focus of our study and to increase the theoretical link with Antle and Eppen's (1985) single-period model.

12 Similar to prior studies with superior rejection authority (e.g., Schatzberg and Stevens 2008; RSY 2008), all of our descriptive statistics and statistical analyses include data from periods where the subordinate's budget was rejected.

13 To control for the lack of independence caused by each participant making multiple decisions, the average level of slack over all decision periods is recorded for each participant and treated as a single observation for all our hypothesis tests utilizing ANOVAs. We estimate a repeated-measure ANOVA to test for Period effects. We find a significant main effect on Period, but no interaction effect of Period and our between-subject variables. Slack is lower in the first five periods than in the last 15 periods, which is driven by low slack in the first two periods. Our results are qualitatively unchanged when excluding the first five periods or analyzing the first five periods alone. 
TABLE 1

Descriptive Statistics: Experiment 1

\begin{tabular}{|c|c|c|c|c|}
\hline \multirow{3}{*}{ No Factual Assertion } & \multicolumn{2}{|c|}{ Public Superior Pay } & \multicolumn{2}{|c|}{ Private Superior Pay } \\
\hline & \multicolumn{2}{|l|}{ Cell 1} & \multicolumn{2}{|l|}{ Cell 3} \\
\hline & Average $\%$ Slack & 0.561 & Average \% Slack & 0.614 \\
\hline & Std. Dev. of Slack & 0.176 & Std. Dev. of Slack & 0.194 \\
\hline & Average Salary & 100 & Average Salary & 100 \\
\hline & $\%$ Rejections & 0.335 & $\%$ Rejections & 0.320 \\
\hline & Average Subordinate Profit & 144.62 & Average Subordinate Profit & 148.87 \\
\hline & Average Superior Profit & 34.97 & Average Superior Profit & 30.33 \\
\hline & \multicolumn{2}{|l|}{ Cell 2} & \multicolumn{2}{|l|}{ Cell 4} \\
\hline \multirow[t]{6}{*}{ Factual Assertion } & Average \% Slack & 0.487 & Average \% Slack & 0.411 \\
\hline & Std. Dev. of Slack & 0.248 & Std. Dev. of Slack & 0.262 \\
\hline & Average Salary & 100 & Average Salary & 100 \\
\hline & $\%$ Rejections & 0.224 & $\%$ Rejections & 0.290 \\
\hline & Average Subordinate Profit & 139.44 & Average Subordinate Profit & 132.36 \\
\hline & Average Superior Profit & 44.70 & Average Superior Profit & 49.10 \\
\hline
\end{tabular}

In each cell, there were 15 participants in the role of subordinates and 15 participants in the role of superiors. The participants interacted for 20 periods in each cell.

Average \% Slack is defined as slack claimed/slack available, and ranges from 0 to 1.

Average Salary is the average salary paid to the manager from the owner's endowment.

$\%$ Rejections is defined as budgets rejected/budgets proposed.

Average Subordinate Profit is defined as the average experimental dollars earned by subordinates from their salary and the project (whether accepted or not).

Average Superior Profit is defined as the average experimental dollars earned by superiors from the project (whether accepted or not).

The average cost of the project was 100.4 experimental dollars in each treatment.

two-tailed) and the hypothesized interactive effect on Factual Assertion and Private Superior Pay $(\mathrm{F}=3.95, \mathrm{p}=0.026$, one-tailed). As reflected in Figure 3, this interaction is in the direction predicted by $\mathrm{H} 1$. To provide further insights regarding this interaction, we analyze the simple main effects within treatments. The results of this analysis are presented in Panel B of Table 2. While Factual Assertion is only marginally significant in the Public Superior Pay treatment $(\mathrm{F}=3.01, \mathrm{p}=$ 0.094, two-tailed), it is highly significant in the Private Superior Pay treatment $(\mathrm{F}=17.06, \mathrm{p}<$ 0.01, two-tailed). The significance of the interaction between Factual Assertion and Private Superior Pay reflects that these two p-values are significantly different. This provides further support for $\mathrm{H} 1$.

Our finding of a marginally significant effect of honesty on budgetary slack under the Public Superior Pay treatment is inconsistent with RSY's finding of no effect for honesty under superior rejection authority. While our study is set in a similar strategic budgeting setting, there are some differences between our two studies that may explain this differential honesty result. Most importantly, the subordinate's salary came out of the superior's endowment in our experiment, whereas the subordinate's salary came directly from the experimenter in RSY. We argue that paying the subordinate's salary out of the superior's endowment captures an important aspect of budgeting settings in practice in that the resources of the firm are limited and the superior is thereby motivated to be efficient with those resources. This design choice was also useful in our experimental study to withhold relative pay information from subordinates in Experiment 1 and to manipulate the ability of the superior to set the subordinate's salary in Experiment 2. Although we 
FIGURE 3

Mean Budgetary Slack across Experimental Conditions Experiment 1

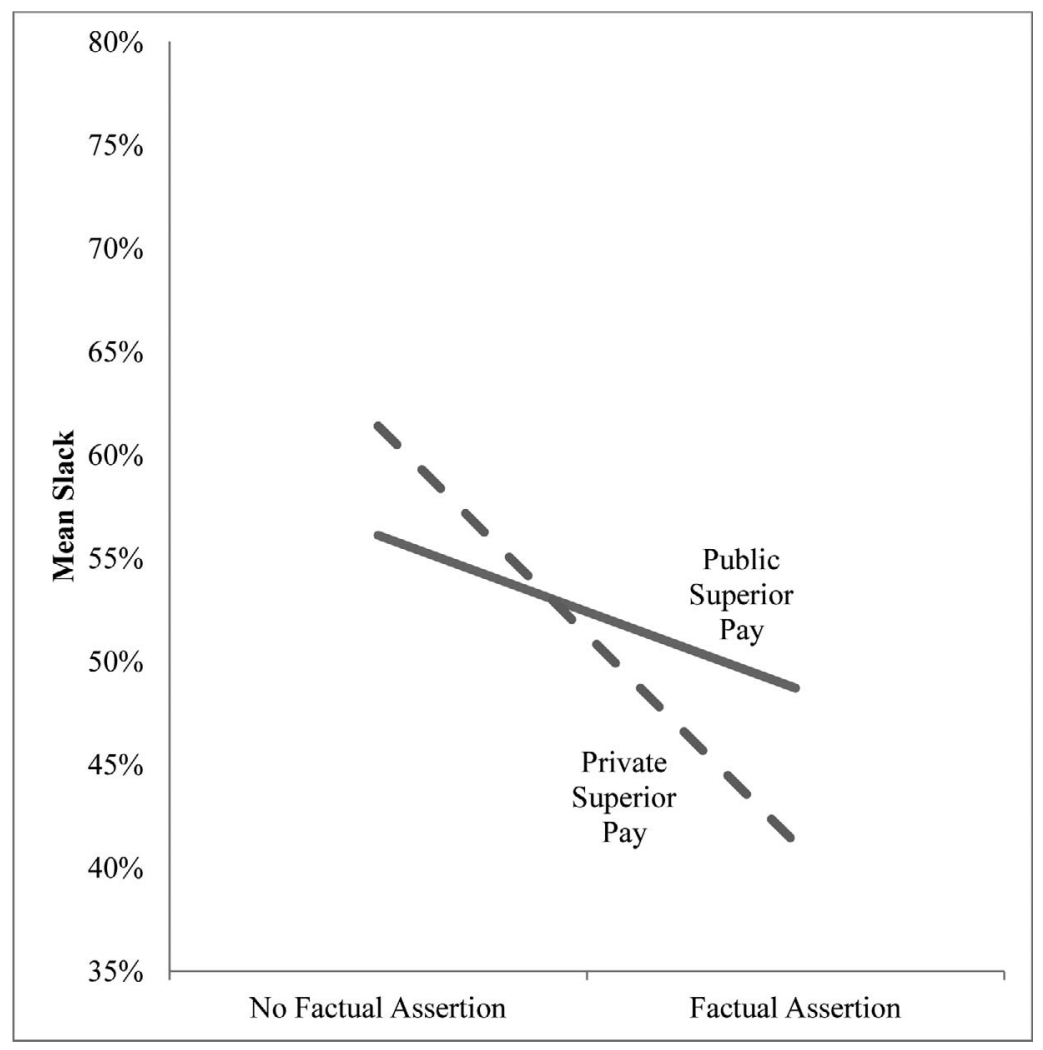

do not directly replicate RSY's no-effect result for honesty under superior authority, the interaction we document between distributional fairness and honesty provides new insights that may explain RSY's result. In particular, our interaction result suggests that the salience of distributional fairness in RSY's experimental setting may have reduced the salience of honesty in their study.

To provide more evidence of the ability of distributional fairness to diminish the incremental effect of honesty on budgetary slack, we include participants' responses to the exit questionnaire item that measured the subordinate's concern for even payoffs ("I wanted both parties to have even payoffs.") as a covariate in our full model. If the interaction term of Factual Assertion and Private Superior Pay is significantly weakened with this covariate in the model, then this would provide evidence that this interaction is driven by the salience of distributional fairness diminishing honesty effects in our experiment. The results of this ANCOVA analysis are presented in Panel C of Table 2. When included in the model as a covariate, the measure of the subordinate's concern for even payoffs (Concerns for Even Payoffs) is significant ( $\mathrm{F}=2.37, \mathrm{p}=0.043$, two-tailed) and the interaction term Factual Assertion $*$ Private Superior Pay is no longer significant $(\mathrm{F}=0.78, \mathrm{p}=$ 0.38 , two-tailed). The main effect for Factual Assertion, however, remains highly significant $(\mathrm{F}=$ 14.37, $\mathrm{p}<0.01$, two-tailed). This ANCOVA analysis supports our interpretation that the interaction we document between Factual Assertion and Private Superior Pay is due to distributional fairness diminishing the effect of honesty on budgetary slack. 
TABLE 2

\section{The Effect of Factual Assertion and Private Superior Pay on Budgetary Slack Experiment 1}

\section{Panel A: Analysis of Variance-Full Model}

\begin{tabular}{lrrrr} 
Factor & & F & & p-value \\
\cline { 1 - 1 } Factual Assertion & & 18.13 & & $<0.001$ \\
Private Superior Pay & & 0.13 & & 0.725 \\
Factual Assertion $*$ Private Superior Pay & & 3.95 & & $\mathbf{0 . 0 2 6}$
\end{tabular}

\section{Panel B: Simple Main Effects}

Factor

Factual Assertion within Public Superior Pay

Factual Assertion within Private Superior Pay

Private Superior Pay within No Factual Assertion

Private Superior Pay within Factual Assertion

\begin{tabular}{|c|c|}
\hline $\mathbf{F}$ & p-value \\
\hline 3.01 & 0.094 \\
\hline 17.06 & $<0.001$ \\
\hline 3.30 & 0.080 \\
\hline 1.72 & 0.201 \\
\hline
\end{tabular}

Panel C: Analysis of Covariance-Concern for Even Payoffs in the Full Model

\begin{tabular}{llcrr} 
Factor & & F & & p-value \\
\cline { 1 - 1 } Factual Assertion & & 14.37 & $<0.001$ \\
Private Superior Pay & & 0.000 & & 0.951 \\
Factual Assertion $*$ Private Superior Pay & & 0.78 & \\
Concern for Even Payoffs (covariate) & & 2.37 & & 0.048
\end{tabular}

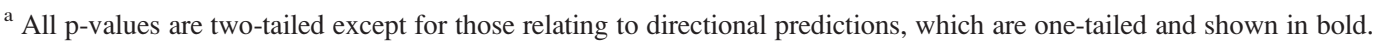
The dependent variable in this analysis is the mean budgetary slack (Slack) for each subordinate over all decision periods.

Variable Definitions:

Slack $=$ each period is calculated as slack claimed/slack available;

Factual Assertion = a dummy variable capturing the mode of budget communication, equaling 1 if the budget report required a factual assertion, and 0 otherwise;

Private Superior Pay = a dummy variable capturing the subordinate's knowledge about the superior's endowment, equal to 0 if the subordinate knew the endowment, and 1 otherwise;

Factual Assertion * Private Superior Pay = interaction term of Factual Assertion and Private Superior Pay; and

Concern for Even Payoffs = measured by the subordinate's response to an exit questionnaire about their agreement with the statement "I wanted both parties to have even payoffs," on a seven-point Likert scale.
}

\section{EXPERIMENT 2: HONESTY AND RECIPROCITY}

\section{Hypothesis Development for Experiment 2}

In Experiment 2, we examine the robustness of honesty effects on budget proposals when the superior has rejection authority by manipulating the salience of reciprocity. Reciprocity is generally defined as repaying intentional actions in like kind, such as repaying kind actions with kindness and unkind actions with unkindness (Rabin 1993; Cox and Deck 2005). Thus, reciprocity requires an intentional act by the first-mover, the nature of which is recognizable by the second-mover so that they may respond in like kind (Fehr and Gachter 2000; Bellemare, Kroger, and van Soest 2011). The effects of reciprocity in labor contracting and as a solution to agency problems have been widely studied in economics and accounting. Experimental researchers have documented "gift 
exchange" behavior whereby superiors pay subordinates above-market wages in exchange for above-minimal effort (Akerlof 1982; Fehr, Kirchsteiger, and Riedl 1993; Hannan 2005; Kuang and Moser 2009; Douthit et al. 2012). Despite the abundance of experimental studies of reciprocity in contracting settings, researchers in accounting have only recently begun to examine reciprocity in a budgeting setting (Schatzberg and Stevens 2008; Zhang 2008).

We argue that honesty and reciprocity represent complementary social norms in a participative budgeting setting. This view is supported by experimental evidence and the supportive nature of honesty and reciprocity norms in a participative budgeting setting. Takahashi et al. (2012) combine personality inventories, economic game theory, and neurobiology to test the relation between honesty and reciprocity norms. They document that honest individuals are more likely to engage in the costly act of reciprocity. Their results suggest that subordinates who are predisposed to the activation of honesty in a budgeting setting are similarly predisposed to the activation of reciprocity. This suggests that increasing the salience of reciprocity norms will not necessarily diminish honesty effects on budgetary slack. Further, behavior that is consistent with a reciprocity norm in a participative budgeting setting is for the subordinate to increase the honesty of the budget after receiving a higher salary from the superior. This behavior supports the honesty norm, and suggests that increasing the salience of reciprocity will support honesty in a budgeting setting.

As discussed above, Bicchieri's (2006, 131) model predicts that where multiple social norms are present, expectations and behavior will be affected by the most salient of the social norms. As situational cues make reciprocity more salient, it increases the probability that this social norm will be activated. In contrast to distributional fairness, however, this need not diminish honesty effects, since reciprocity and honesty norms do not make conflicting prescriptions in our experimental setting. Further, Bicchieri's $(2006,70)$ model predicts that social norms can be elicited indirectly by focusing on other, conceptually similar norms. We expect that giving the superior the authority to set the salary of the subordinate is a powerful situational cue that makes reciprocity salient. Thus, we manipulate the salience of reciprocity norms by manipulating the salary authority of the superior, and we expect honesty effects on budgetary slack to be robust to the presence of this authority. Based on Bicchieri's (2006) model and experimental evidence, in H2, we predict that honesty will have an effect on budgetary slack when the superior sets the salary of the subordinate:

H2: Honesty will have an effect on budgetary slack when the superior sets the salary of the subordinate.

\section{Experimental Design for Experiment 2}

To test our second hypothesis, we extend the Private Superior Pay treatment from Experiment 1 , where the salience of distributional fairness is decreased, by manipulating the salience of reciprocity. In particular, we utilize a $2 \times 2$ factorial design where the authority of the superior to set the subordinate's salary is manipulated at two levels (No Salary Authority versus Salary Authority) and the mode of budget communication is manipulated at two levels (Factual Assertion versus No Factual Assertion). The first manipulation allows us to examine the robustness of honesty effects to the salience of reciprocity norms, and the second manipulation allows us to capture the incremental effect of honesty on budgetary slack.

The timeline for Experiment 2 is presented in Figure 4. As in Experiment 1, the superior received an initial endowment of 100 experimental dollars, out of which she paid the subordinate's salary. While the presence of the endowment was common knowledge, the amount of the endowment was known only by the superior. Under the No Salary Authority treatment, the superior had to pay the subordinate a salary of 100 experimental dollars each period, as in Experiment 1 . As such, this treatment created an experimental budgeting setting where the salience of reciprocity 


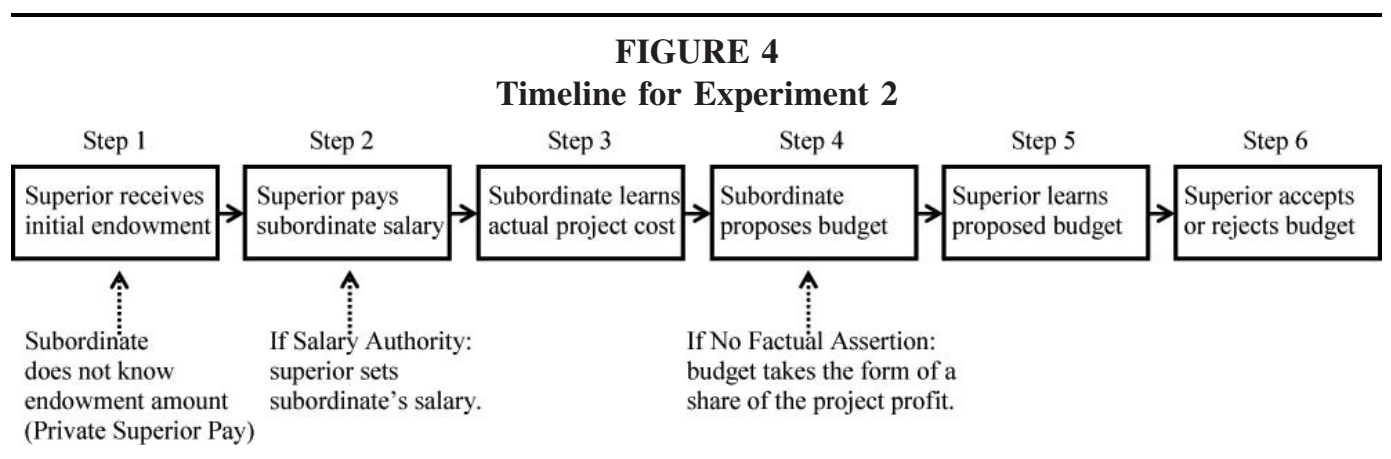

After Step 6, managers and owners are randomly rematched and steps 1-6 repeat for a total of 20 periods.

norms was reduced. Under the Salary Authority condition, it was common knowledge that the superior chose the salary paid to the subordinate out of the superior's endowment each period. Prior to learning the actual cost of the project, the subordinate was informed of the amount of the salary set by the superior he was paired with that period. Any amount of the endowment not used to pay the subordinate's salary was kept by the superior. Since the superior made an intentional choice that could be perceived by the subordinate as more or less kind, this treatment created an experimental budgeting setting in which the salience of reciprocity was increased. All other aspects of Experiment 2 were identical to Experiment 1.

In the experimental treatment in which the superior does not have the authority to set the subordinate's salary (No Salary Authority), the same strong economic predictions as in Experiment 1 hold based on traditional game theory (Camerer 2003). That is, the subordinate is predicted to report the highest possible cost or offer the superior the lowest possible profit from the project, and the superior is predicted to always accept the project in order to maximize her wealth. In the experimental treatment in which the superior has salary authority, however, the superior is predicted to pay the subordinate a salary of zero and keep the entire endowment for herself because she can pay less than her full endowment and she expects to receive the minimal share of the project profit from the subordinate. Since the No Salary Authority treatment in Experiment 2 is exactly the same as the Private Superior Pay treatment from Experiment 1, we only collect additional data for the Salary Authority condition for Experiment 2 (see Figure 1). Experiment 2 was conducted in eight sessions, with 14 participants in half of the sessions and 16 participants in the rest of the sessions. Each session lasted about 45 minutes, and the average earnings per participant were $\$ 18.95$, in addition to the $\$ 10$ show-up fee.

\section{Results for Experiment 2}

As with Experiment 1, participants responded to a number of statements on the exit questionnaire that were designed to test the effectiveness of our experimental manipulations and controls using a seven-point Likert scale $(1=$ Strongly Disagree, $7=$ Strongly Agree $)$. Tests of manipulations and controls are the mean difference from the neutral response of 4 . In untabulated results, we find evidence that our experimental manipulations and controls were effective for Experiment 2 (all $\mathrm{p}<0.05$ ). In particular, keeping the relative pay of the superior private reduced the salience of distributional fairness in all four experimental cells, and manipulating the ability of the superior to set the subordinate's salary increased the salience of reciprocity.

Descriptive statistics for Experiment 2 are presented in Table 3. Slack is the highest in the Salary Authority/No Factual Assertion treatment, followed by the No Salary Authority/No Factual 
TABLE 3

\section{Descriptive Statistics: Experiment 2}

\begin{tabular}{|c|c|c|c|c|}
\hline \multirow{3}{*}{ No Factual Assertion } & \multicolumn{2}{|c|}{ No Salary Authority } & \multicolumn{2}{|l|}{ Salary Authority } \\
\hline & \multicolumn{2}{|l|}{ Cell 3} & \multicolumn{2}{|l|}{ Cell 5} \\
\hline & Average \% Slack & 0.614 & Average \% Slack & 0.656 \\
\hline & Std. Dev. of Slack & 0.194 & Std. Dev. of Slack & 0.246 \\
\hline & Average Salary & 100 & Average Salary & 30.50 \\
\hline & $\%$ Rejections & 0.320 & $\%$ Rejections & 0.183 \\
\hline & Average Subordinate Profit & 148.87 & Average Subordinate Profit & 88.48 \\
\hline & Average Superior Profit & 30.33 & Average Superior Profit & 101.38 \\
\hline & \multicolumn{2}{|l|}{ Cell 4} & \multicolumn{2}{|l|}{ Cell 6} \\
\hline \multirow[t]{6}{*}{ Factual Assertion } & Average \% Slack & 0.411 & Average \% Slack & 0.513 \\
\hline & Std. Dev. of Slack & 0.262 & Std. Dev. of Slack & 0.256 \\
\hline & Average Salary & 100 & Average Salary & 30.37 \\
\hline & $\%$ Rejections & 0.290 & $\%$ Rejections & 0.233 \\
\hline & Average Subordinate Profit & 132.36 & Average Subordinate Profit & 72.96 \\
\hline & Average Superior Profit & 49.10 & Average Superior Profit & 113.43 \\
\hline
\end{tabular}

In each cell, there were 15 participants in the role of subordinates and 15 participants in the role of superiors. The participants interacted for 20 periods in each cell.

Average \% Slack is defined as slack claimed/slack available, and ranges from 0 to 1.

Average Salary is the average salary paid to the subordinate from the superior's endowment.

$\%$ Rejections is defined as budgets rejected/budgets proposed.

Average Subordinate Profit is defined as the average experimental dollars earned by subordinates from their salary and the project (whether accepted or not).

Average Superior Profit is defined as the average experimental dollars earned by superiors from their residual endowment (in Cells 5 and 6) and the project (whether accepted or not).

The average cost of the project was 100.4 experimental dollars in each treatment.

Assertion treatment, the Salary Authority/Factual Assertion treatment, and then the No Salary Authority/Factual Assertion treatment. These means are graphed in Figure 5.

In $\mathrm{H} 2$, we predict that honesty will have an effect on budgetary slack when the superior sets the salary of the subordinate. To test this prediction, we estimate an ordinary least squares (OLS) regression of the effect of the factual assertion (Factual Assertion), the salary set by the superior (Salary), and the interaction of these two factors on budgetary slack while clustering the error terms of each subordinate to control for the repeated-measures nature of responses. To find the effect of the mode of budget communication at the average salary and the average effect of the salary level across the two modes of budget communication, we center Factual Assertion and Salary so the mean value of these unadjusted variables is loaded into the regression as $0 .{ }^{14}$

We report the results of this analysis in Panel A of Table 4. Consistent with Zhang (2008), subordinates in our study reciprocate higher salaries from the superior by claiming lower slack, as evidenced by a negative coefficient on Salary $(\mathrm{t}=-7.94, \mathrm{p}<0.01$, one-tailed). More importantly, consistent with $\mathrm{H} 2$, we find that honesty effects on budgetary slack are robust to the salience of

14 This is accomplished by subtracting the unadjusted mean for each variable from each observation so that Salary and Factual Assertion have a mean of zero. As such, the main effect of Salary can be interpreted as the effect of salary across factual assertion treatment, and the main effect of Factual Assertion can be interpreted as the effect of the factual assertion manipulation at the average salary (i.e., when Salary equals zero). 
FIGURE 5

Mean Budgetary Slack across Experimental Conditions Experiment 2

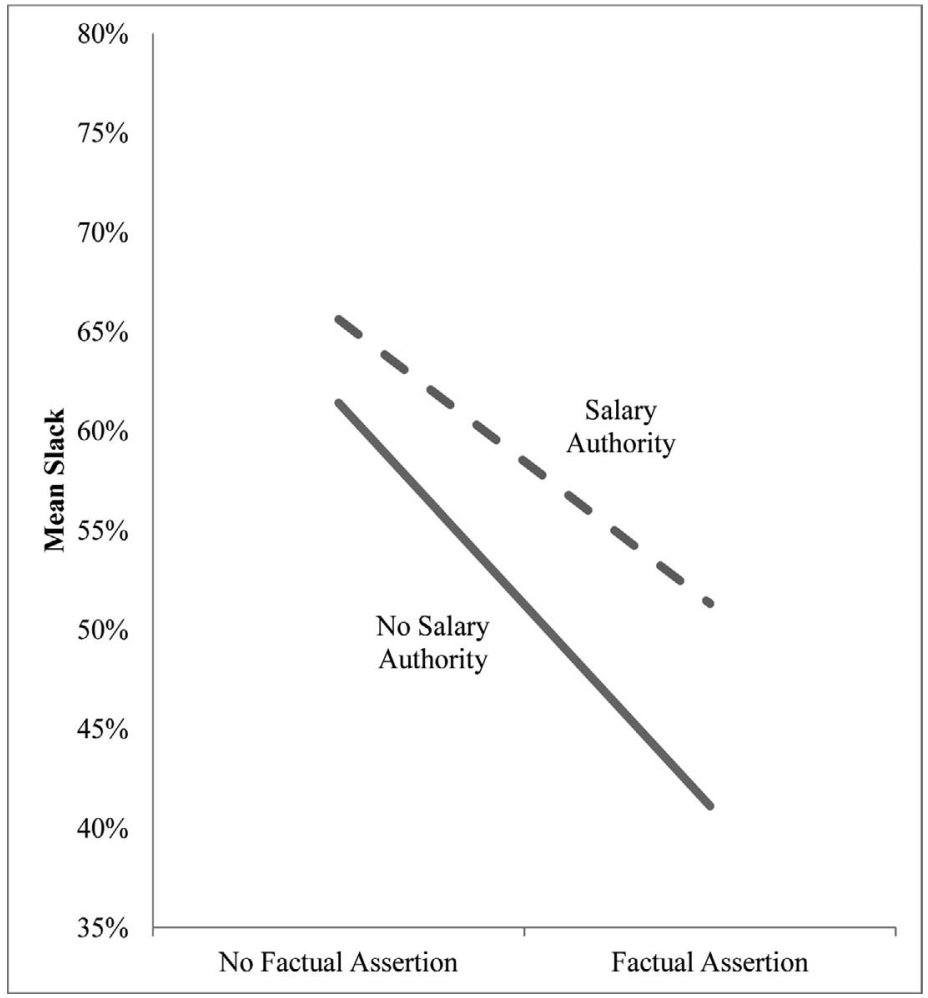

reciprocity norms. This is evidenced by an insignificant interaction between Factual Assertion and Salary $(\mathrm{t}=0.13, \mathrm{p}>0.10)$ and a negative main effect for Factual Assertion $(\mathrm{t}=-2.74, \mathrm{p}<0.01$, one-tailed). Across salary levels, budgetary slack is significantly lower when the budget communication included a factual assertion than when it did not.

To provide further evidence regarding H2, we estimate an ANOVA on the effect of Factual Assertion, Salary Authority, and the interaction of these two dummy variables on budgetary slack. The results of this analysis are presented in Panel B of Table 4. We find a significant main effect for Factual Assertion $(\mathrm{F}=17.46, \mathrm{p}<0.01)$ and Salary Authority $(\mathrm{F}=6.35, \mathrm{p}=0.02$, two-tailed $)$, but an insignificant interaction between Factual Assertion and Salary Authority $(\mathrm{F}=0.51, \mathrm{p}=0.48$, two-tailed). This evidence suggests that the salience of reciprocity does not diminish the incremental effect of honesty on budget proposals. To provide more evidence for the robustness of honesty effects on budgetary slack when the salience of reciprocity is manipulated, we present the simple main effects in Panel $\mathrm{C}$ of Table 4. We find a highly significant main effect for Factual Assertion both when the superior has salary authority $(\mathrm{F}=6.26, \mathrm{p}<0.01$, one-tailed $)$ and when the superior does not have salary authority $(\mathrm{F}=17.06, \mathrm{p}<0.01)$. In summary, we find strong and consistent support for $\mathrm{H} 2$.

As explained above, traditional game theory predicts that the superior would set the salary of the subordinate at zero under salary authority because this allows her to keep her full endowment and she expects to receive the minimal share of the project profit from the subordinate. In contrast to 


\section{TABLE 4}

\section{The Effect of Factual Assertion and Salary Authority on Budgetary Slack: Experiment 2}

\section{Panel A: OLS Regression of Budgetary Slack with Salary Authority Effects}

\begin{tabular}{lc} 
& $\begin{array}{c}\text { Coefficient } \\
(\mathbf{t}-\text { stat })\end{array}$ \\
\cline { 2 - 2 } Factual Assertion & -0.124 \\
& $(-2.74)^{* * *}$ \\
Salary & -0.004 \\
& $(-7.94)^{* * *}$ \\
Factual Assertion $*$ Salary & 0.000 \\
$\mathrm{R}^{2}=0.1802$ & $(0.13)$
\end{tabular}

*** Represents significance at the 1 percent level.

\section{Panel B: Analysis of Variance-Full Model}

\begin{tabular}{|c|c|c|}
\hline Factor & $\mathbf{F}$ & p-value ${ }^{a}$ \\
\hline Factual Assertion & 17.46 & $<0.001$ \\
\hline Salary Authority & 6.35 & 0.015 \\
\hline Factual Assertion $*$ Salary Authority & 0.51 & 0.479 \\
\hline
\end{tabular}

\section{Panel C: Simple Main Effects}

\begin{tabular}{llrrr} 
Factor & & F & p-value \\
${$\cline { 1 - 1 }$} }$ & & 17.06 & & $<0.001$ \\
Factual Assertion within Salary Authority & & 6.26 & & $\mathbf{0 . 0 0 9}$ \\
Salary Authority within No Factual Assertion & 0.60 & & 0.446 \\
Salary Authority within Factual Assertion & & 3.87 & & 0.059
\end{tabular}

\footnotetext{
${ }^{a}$ All p-values are two-tailed except for those relating to directional predictions, which are one-tailed and presented in bold.

The dependent variable in these analyses is Slack, which is the mean slack for each subordinate over all decision periods.

Variable Definitions:

Slack $=$ each period is calculated as slack claimed/slack available;

Factual Assertion = a dummy variable for the mode of budget communication, equal to 1 if the budget report required a factual assertion, and 0 otherwise, centered at the mean of the dummy variable;

Salary $=$ salary set by the superior for the subordinate, centered at the mean of salary set;

Salary Authority = a dummy variable for the superior's ability to set the subordinate's salary, equal to 1 if the superior set the subordinate's salary, and 0 otherwise;

Factual Assertion $*$ Salary = interaction term of Factual Assertion and Salary; and

Factual Assertion * Salary Authority = interaction term of Factual Assertion and Salary Authority.
}

this stark economic prediction, however, the average salary set by the superior under salary authority is 30 (see Table 3). The average salary appears generous in view of traditional game theory, but is well below the required salary of 100 when the superior did not have salary authority. Because the average salary is above zero, it provides evidence that superiors expected the subordinate to reciprocate higher salary levels by building less budgetary slack. Because the average salary is below 100, it helps explain why budgetary slack levels were higher, on average, when the superior had salary authority. 


\section{Supplemental Analyses of Superior Rejection Behavior in Experiment 2}

As discussed previously, Bicchieri's (2006) model suggests that a social norm is activated and followed when individuals become aware that a given norm is relevant to the current social setting and a combination of empirical and normative expectations gives individuals a sufficient reason to follow the norm. Normative expectations are based on the belief that a sufficiently large subset of people expects conformance to the norm in similar settings and may be willing to sanction behavior inconsistent with the norm. Therefore, normative expectations and the potential sanctioning behavior of the referent group play an important role in social norm activation. This suggests that social norms activated by the budgeting setting will affect the expectations and behavior of the superior, in addition to the subordinate. Given that the superior could sanction the behavior of the subordinate by rejecting the budget, the rejection behavior of the superior could play an important role in supporting honesty and reciprocity norms in the subordinate. Therefore, based on Bicchieri's (2006) model, we expect superiors to be more likely to reject budget proposals that contain high levels of budgetary slack when social norms for honesty or reciprocity have been activated, controlling for the level of the budget reported.

To test the effect of honesty and reciprocity norms on superior rejection behavior, we use a logistic regression of the effects of the mode of budget communication (Factual Assertion), the salary chosen for the subordinate (Salary), and the generosity of the budget report (Generosity) on the rejection decision when the superior has Salary Authority. Generosity is the amount of money the superior would receive from the project if she accepted the subordinate's report. The error terms are clustered at the participant level to control for the repeated-measures nature of responses. The results of this analysis are presented in Table 5. Generosity is a significant predictor of rejection behavior $(\mathrm{z}=-6.76, \mathrm{p}<0.01)$. Nevertheless, the coefficient on Factual Assertion is positive and significant $(\mathrm{z}=2.19, \mathrm{p}=0.014$, one-tailed), as is the coefficient on Salary $(\mathrm{z}=2.41, \mathrm{p}<0.01$, onetailed). Thus, controlling for the generosity of the subordinate's budget request, the activation of honesty and reciprocity norms appeared to increase the likelihood that the superior would reject the budget. ${ }^{15}$ We conclude, consistent with Bicchieri's (2006) model, that activated social norms for honesty and reciprocity affected the expectations and behavior of the superior, in addition to the subordinate.

\section{Supplemental Analyses of Firm Profit in Experiment 2}

From an agency theory perspective, the main importance of honesty and reciprocity norms to participative budgeting is their effectiveness at mitigating reductions in the profitability of the principal-agent relation due to information asymmetry and economic self-interest. As such, it is important to test whether such social norms lead to higher profits for the superior. To examine the effect of honesty and reciprocity on superior profit, we estimate an ANOVA of the effect of Factual Assertion, Salary Authority, and the interaction of these two dummy variables on the superior's earnings. As with our ANOVAs analyzing budgetary slack, we control for the lack of independence in participants' multiple responses by averaging earnings for each superior over all periods and treating this mean as a single observation. The results of this analysis are presented in Panel A of Table 6. We find that both main effects have a significant effect on the superior's payoff. In particular, superior earnings are higher when the budget communication required a factual assertion $(\mathrm{F}=24.07$, $\mathrm{p}<0.01)$ and when the superior had salary authority $(\mathrm{F}=464.00, \mathrm{p}<0.01)$. The significant effect of Factual Assertion on firm profit suggests that honesty increased the profitability of the principal-agent

\footnotetext{
15 We investigated the two-way and three-way interaction of these factors and found no interaction between them. The inclusion of these interaction effects does not qualitatively change our results. In untabulated results, we find a significant effect of the factual assertion in the No Salary Authority treatment $(\mathrm{z}=1.87, \mathrm{p}=0.03$, one-tailed).
} 
TABLE 5

$\begin{aligned} & \text { Results of Logit Regression of Factual Assertion, Salary, and Reporting Generosity on } \\ & \text { Rejection Decisions of the Superior: Experiment } 2 \\ & \text { Coefficient } \\ & \text { (z-stat) }\end{aligned}$
$\begin{array}{ll}\text { Factual Assertion } & 0.871 \\ & (2.19)^{* *} \\ \text { Salary } & 0.019 \\ & (2.41)^{* *} \\ \text { Generosity } & -0.064 \\ \text { Log pseudo-likelihood }=-233.509 & (-6.76)^{* * *}\end{array}$

**,*** Represent two-tailed significance at the 5 percent and 1 percent levels, respectively.

The dependent variable in this regression is Reject. The error terms for this regression are clustered at the subject level.

Variable Definitions:

Reject $=$ a dichotomous variable equal to 1 when a project is rejected by the superior, and 0 otherwise;

Factual Assertion = a dummy variable for the mode of budget communication manipulation, equal to 1 if the budget report required a factual assertion, and 0 otherwise;

Salary $=$ salary set by the superior for the subordinate each period; and

Generosity = level of profit from the project that would be realized by the superior if the project was accepted.

relation for the superior, consistent with honesty mitigating agency problems in this setting. The significant effect of Salary Authority on firm profit suggests that superiors had a somewhat accurate expectation about the level of reciprocity to expect from subordinates. The Factual Assertion * Salary Authority interaction term is insignificant $(\mathrm{F}=1.14, \mathrm{p}>0.10)$ and the simple main effects in Panel B of Table 6 verify the robustness of the honesty and reciprocity effects on firm profit.

Given the significant effect of Salary Authority on superior profit, we further examine the determinants of superior profit in the Salary Authority treatment. In particular, we estimate a clustered OLS regression of the effect of the factual assertion (Factual Assertion), linear and nonlinear effects of salary (Salary and Salary ${ }^{2}$, respectively), and the interactive effects of the factual assertion with the linear and nonlinear salary effects in the Salary Authority treatments on the superior's earnings. ${ }^{16}$ As before, Factual Assertion and Salary are centered so the mean value of the unadjusted variables is equal to zero and the higher order terms are the interactions of the centered variables. The results of this regression are presented in Panel $\mathrm{C}$ of Table 6 . We find that Salary is negatively related to superior profit $(\mathrm{t}=-15.55, \mathrm{p}<0.01)$, but this negative relationship becomes less negative as the salary increases, as reflected in the significantly positive coefficient on $\operatorname{Salary}^{2}(\mathrm{t}=3.32, \mathrm{p}<0.01)$. Thus, while increasing the subordinate's salary decreased the level of budgetary slack, it did so at a rate of less than one-to-one. Superiors appear to have partially anticipated the reciprocal response to salaries and improved their payoffs by choosing positive, but low, salaries for subordinates. However, the average response of the subordinate to salary changes was sufficiently small that the profit-maximizing salary was zero. As such, superiors were only partially successful at reaping higher profits through reciprocity when they could set the subordinate's salary. Collectively, our results suggest that honesty continued to play an important role in mitigating agency problems in the presence of reciprocity.

${ }^{16}$ We test for nonlinear effects of the salary since prior literature on gift exchange-type relationships have found nonlinearity in the response to different salary levels (e.g., Hannan 2005). 


\section{TABLE 6}

\section{The Effect of Budget Communication and Salary Authority on Firm Profit: Experiment 2}

Panel A: Analysis of Variance-Full Model

\begin{tabular}{|c|c|c|}
\hline Factor & $\mathbf{F}$ & p-value \\
\hline Factual Assertion & 24.07 & $<0.001$ \\
\hline Salary Authority & 464.00 & $<0.001$ \\
\hline Factual Assertion $*$ Salary Authority & 1.14 & 0.291 \\
\hline
\end{tabular}

\section{Panel B: Simple Main Effects}

\begin{tabular}{llrrr} 
Factor & & F & & p-value \\
\cline { 1 - 1 } Factual Assertion within No Salary Authority & & 27.91 & & $<0.001$ \\
Factual Assertion within Salary Authority & & 5.42 & & 0.027 \\
Salary Authority within No Factual Assertion & & 423.63 & & $<0.001$ \\
Salary Authority within Factual Assertion & & 150.06 & & $<0.001$
\end{tabular}

\section{Panel C: Clustered OLS Regression of Firm Profit with Salary Authority Effects}

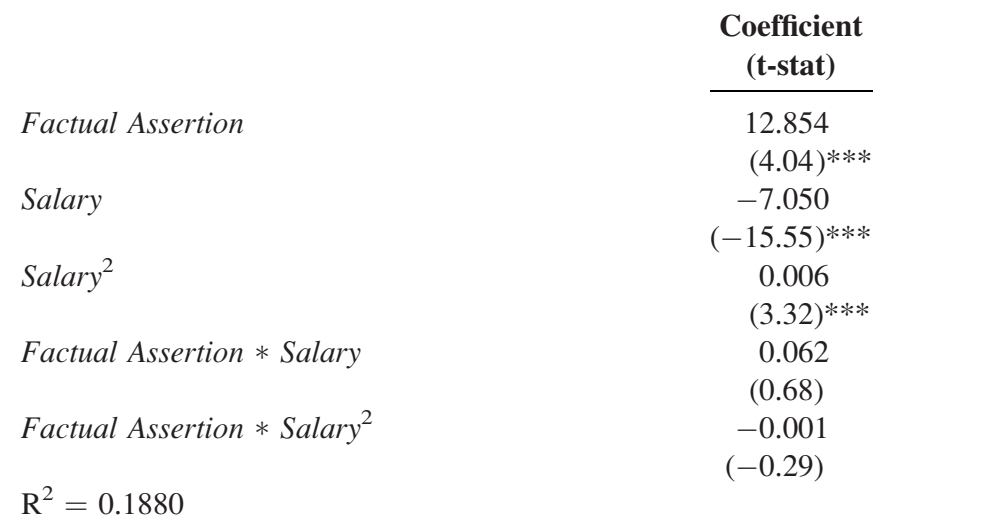

\footnotetext{
*** Represents significance at the 1 percent level.

The dependent variable in these analyses is Firm Profit.

Variable Definitions:

Firm Profit = earnings for each superior over all decision periods;

Factual Assertion = a dummy variable for the mode of budget communication, equal to 1 if the budget report required a factual assertion, and 0 otherwise, centered at the mean of the dummy variable;

Salary = salary set by the superior for the subordinate, centered at the mean of salary set;

Salary $^{2}=$ interaction term of Salary and Salary;

Factual Assertion $*$ Salary $=$ interaction term of Factual Assertion and Salary; and

Factual Assertion $*$ Salary $^{2}=$ interaction term of Factual Assertion and Salary ${ }^{2}$.
}

\section{CONCLUSION}

Rankin et al. (2008; RSY) examine the effect of honesty on budget proposals in a participative budgeting setting by manipulating the mode of communication of the budget proposal, such that subordinates either provide a factual assertion of actual project cost or propose a division of the project profit without a factual assertion. They find no effect of honesty on budgetary slack when 
the superior can reject the subordinate's budget proposal. Using RSY's manipulation to capture honesty effects, we examine the robustness of honesty effects on budget proposals when the superior has rejection authority in two experiments. In Experiment 1, we document that honesty has a strong effect on budgetary slack when the salience of distributional fairness is reduced by withholding the relative pay of the superior from the subordinate. In Experiment 2, we document that honesty continues to have a strong effect on budgetary slack when the salience of reciprocity is increased by giving the superior the ability to set the subordinate's salary. Thus, our evidence suggests that honesty effects on budget proposals are generally robust to giving the superior rejection authority. In supplemental analysis of superior rejection behavior, we find that superiors were willing to engage in the costly behavior of rejecting the budget to enforce honesty and reciprocity norms in the subordinate's budget.

Our study follows the suggestions in Brown et al. (2009) regarding the conditions in which experiments have the greatest potential to extend traditional agency theory. We utilize a baseline prediction from the agency model of participative budgeting in Antle and Eppen (1985), and incorporate insights from Bicchieri's (2006) model of social norm activation to explain why our results are expected to deviate from that baseline prediction. We find Bicchieri's (2006) model useful in predicting how situational cues present in the budgeting setting can affect the salience of certain social norms, and how the salience of such norms interacts with the honesty norm in this setting. In particular, we find Bicchieri's (2006) model useful in providing an alternative explanation for RSY's result that honesty did not affect budgetary slack under superior rejection authority. Our theoretical development and experimental results offer a novel interpretation of RSY's main result based on competing social norms.

Our results suggest that it is premature to conclude from RSY's experimental study that honesty plays no role in strategic participative budgeting settings. While superiors typically have rejection authority, subordinates rarely know the relative pay of their superiors in practice, as they did in RSY. We document that honesty has a strong effect on budgetary slack when the subordinate does not know the relative pay of the superior. This increases our confidence that honesty plays an important role in participative budgeting in practice. Our confidence in the importance of honesty is further increased by our finding that the effect of honesty is robust to the salience of reciprocity when the superior sets the subordinate's salary. The authority to set subordinate pay is implicit in the hierarchical relationship between the superior and the subordinate in typical budgeting settings. Finally, our confidence in the importance of honesty is increased by our finding that the rejection behavior of the superior is also affected by honesty expectations in a way that enforces this social norm.

Our results support recent experimental evidence in accounting demonstrating that contextual cues can activate social norms that control opportunistic behavior across an increasing number of economic settings. For example, Tayler and Bloomfield (2011) show that social norms can control opportunism in the presence of formal controls, while Davidson and Stevens (2013) show that social norms can control opportunism through a manager's certification of a code of ethics. Our results also support the effort by some theorists to incorporate social norms into traditional agency theory. While the possibility for social norms to control opportunistic behavior was raised early in the development of agency theory (Demski and Feltham 1978, 346), theorists have only recently incorporated this possibility into their models. For example, Mittendorf (2006) incorporates honesty preferences into a hidden-information, capital-budgeting model and examines the implications of this disutility for the owner's choice of transfer payments and cost hurdles, while Stevens and Thevaranjan (2010) incorporate a morally sensitive agent in the traditional hiddenaction, principal-agent model and examine the implications for the moral hazard problem. Consistent with these theoretical and experimental studies, our study suggests that adding social norms increases the descriptive usefulness of traditional agency theory. 
As with prior experimental studies of participative budgeting, our study contains a stark experimental setting that is designed to provide a strong test of relevant theory. Although we implement a somewhat richer experimental setting than previous studies by giving the superior rejection and salary authority, our experimental setting still abstracts significantly from budgeting settings in practice. To the extent that our experimental design captures important aspects of these settings, however, we believe that our results provide useful insights that may generalize to such settings. Future research may provide additional insights by enriching the budgeting setting to include such factors as uncertainty in project cost, iterative bargaining, and repeated interactions between the superior and the subordinate. Our results suggest that future research is warranted to examine the main and interactive effects of social norms in participative budgeting settings. In particular, incorporating social norm theory may expand and enrich the "nexus of contracts" view of the firm in agency theory.

\section{REFERENCES}

Akerlof, G. 1982. Labor contracts as partial gift exchange. Quarterly Journal of Economics 97 (4): $543-$ 569.

Andreoni, J., and D. Bernheim. 2009. Social image and the 50-50 norm: A theoretical and experimental analysis of audience effects. Econometrica 77 (5): 1607-1636.

Antle, R., and G. Eppen. 1985. Capital rationing and organizational slack in capital budgeting. Management Science 31 (2): 163-174.

Baiman, S. 1990. Agency research in managerial accounting: A second look. Accounting, Organizations and Society 15 (4): 341-371.

Baiman, S., and J. H. Evans III. 1983. Pre-decision information and participative management control systems. Journal of Accounting Research 21 (2): 371-395.

Bellemare, C., S. Kroger, and A. van Soest. 2011. Preferences, intentions, and expectation violations: A large-scale experiment with a representative subject pool. Journal of Economic Behavior and Organization 78 (3): 349-365.

Bicchieri, C. 2006. The Grammar of Society: The Nature and Dynamics of Social Norms. New York, NY: Cambridge University Press.

Bicchieri, C. 2008. The fragility of fairness: An experimental investigation on the conditional status of prosocial norms. Philosophical Issues 18: 229-248.

Blount, S. 1995. When social outcomes aren't fair: The effect of causal attribution on preferences. Organizational Behavior and Human Decision Processes 63: 131-144.

Brown, J., J. H. Evans III, and D. Moser. 2009. Agency theory and participative budgeting experiments. Journal of Management Accounting Research 21 (1): 317-345.

Camerer, C. 2003. Behavioral Game Theory: Experiments in Strategic Interaction. Princeton, NJ: Princeton University Press.

Carpenter, J. 2002. Information, fairness, and reciprocity in the best shot game. Economic Letters 75 (2): 243-248.

Charness, G., and U. Gneezy. 2008. What's in a name? Anonymity and social distance in dictator and ultimatum games. Journal of Economic Behavior and Organization 68 (1): 29-35.

Chow, C., J. Cooper, and W. Waller. 1988. Participative budgeting: Effects of a truth-inducing pay scheme and information asymmetry on slack and performance. The Accounting Review 63 (1): 111-122.

Cooper, D., and J. Kagel. 2015. Other-regarding preferences: A survey of experimental results. In The Handbook of Experimental Economics, Vol. 2, edited by Kagel, J., and A. Roth (forthcoming).

Cox, J., and C. Deck. 2005. On the nature of reciprocal motives. Economic Inquiry 43 (3): 623-635.

Croson, R. 1996. Information in ultimatum games: An experimental study. Journal of Economic Behavior and Organization 30 (2): 197-212.

Cyert, R., and J. March. 1963. A Behavioral Theory of the Firm. Englewood Cliffs, NJ: Prentice Hall. 
Dana, J., R. Weber, and X. Kuang. 2007. Exploiting moral wiggle room: Experiments demonstrating an illusory preference for fairness. Economic Theory 33 (1): 67-80.

Davidson, B., and D. Stevens. 2013. Can a code of ethics improve manager behavior and investor confidence? An experimental study. The Accounting Review 88 (1): 51-74.

Demski, J., and G. Feltham. 1978. Economic incentives in budgetary control systems. The Accounting Review 53 (2): 336-359.

Douthit, J., L. Kearney, and D. Stevens. 2012. Can agent cheap talk mitigate agency problems in the presence of a noisy performance measure? An experimental test in a single- and multi-period setting. Journal of Management Accounting Research 24: 135-158.

Evans, J. H. III, R. Hannan, R. Krishnan, and D. Moser. 2001. Honesty in managerial reporting. The Accounting Review 76 (4): 537-559.

Falk, A., E. Fehr, and U. Fischbacher. 2003. On the nature of fair behavior. Economic Inquiry 41 (1): 20 26.

Fehr, E., and K. Schmidt. 1999. A theory of fairness, competition, and cooperation. Quarterly Review of Economics 114 (3): 817-868.

Fehr, E., and S. Gachter. 2000. Fairness and retaliation: The economics of reciprocity. The Journal of Economic Perspectives 14 (3): 159-181.

Fehr, E., G. Kirchsteiger, and A. Riedl. 1993. Does fairness prevent market clearing? An experimental investigation. The Quarterly Journal of Economics 108 (2): 437-459.

Fischbacher, U. 2007. z-Tree: Zurich toolbox for ready-made economic experiments. Experimental Economics 10 (2): 171-178.

Gino, F., and L. Pierce. 2010. Lying to level the playing field: Why people may dishonestly help or hurt others to create equity. Journal of Business Ethics 95: 89-103.

Guth, W. 1995. On ultimatum bargaining experiments: A personal review. Journal of Economic Behavior and Organizations 27: 329-344.

Guth, W., R. Schmittberger, and B. Schwarze. 1982. An experimental analysis of ultimatum games. Journal of Economic Behavior and Organizations 3: 367-388.

Guth, W., S. Huck, and W. Muller. 2001. The relevance of equal splits in ultimatum games. Games and Economic Behavior 37 (1): 161-169.

Hannan, L. 2005. The combined effect of wages and firm profit on employee effort. The Accounting Review 80 (1): $167-188$.

Hannan, L., F. Rankin, and K. Towry. 2006. The effect of information systems on honesty in managerial reporting: A behavioral perspective. Contemporary Accounting Research 23 (4): 885-915.

Hannan, L., F. Rankin, and K. Towry. 2010. Flattening the organization: The effect of organizational reporting structure on budgeting effectiveness. Review of Accounting Studies 15 (3): 503-536.

Hoffman, E., K. McCabe, and V. Smith. 2000. The impact of exchange context on the activation of equity in ultimatum games. Experimental Economics 3 (1): 5-9.

Jensen, M. 2001. Corporate budgeting is broken, let's fix it. Harvard Business Review (November): 94-101.

Jensen, M., and W. Meckling. 1976. Theory of the firm: Managerial behavior, agency costs and ownership structure. Journal of Financial Economics 3 (4): 305-360.

Kachelmeier, S., and K. Towry. 2002. Negotiated transfer pricing: Is fairness easier said than done? The Accounting Review 77 (3): 571-593.

Kagel, J., C. Kim, and D. Moser. 1996. Fairness in ultimatum games with asymmetric information and asymmetric payoffs. Games and Economic Behavior 13 (1): 100-110.

Kren, L., and W. Liao. 1988. The role of accounting information in the control of organizations: A review of the evidence. Journal of Accounting Literature 7 (1): 280-309.

Kuang, X., and D. Moser. 2009. Reciprocity and the effectiveness of optimal agency contracts. The Accounting Review 84 (5): 1671-1694.

Libby, T., and M. Lindsay. 2007. Beyond budgeting or better budgeting? Strategic Finance (2): 46-51.

Libby, T., and M. Lindsay. 2010. Beyond budgeting or budgeting reconsidered? A survey of NorthAmerican budgeting practice. Management Accounting Research 21 (1): 56-75. 
Merchant, K. 1985. Budgeting and the propensity to create budgetary slack. Accounting, Organizations and Society 10 (2): 201-210.

Mittendorf, B. 2006. Capital budgeting when managers value both honesty and perquisites. Journal of Management Accounting Research 18 (1): 77-95.

Murphy, K. 1993. Honesty in the Workplace. Pacific Grove, CA: Brooks/Cole.

Neely, A., R. Sutcliff, and H. Heyns. 2001. Driving Value Through Strategic Planning and Budgeting. New York, NY: Accenture.

Rabin, M. 1993. Incorporating fairness into economics and game theory. American Economic Review 83 (5): 1281-1302.

Rankin, F., S. Schwartz, and R. Young. 2008. The effect of honesty and superior authority on budget proposals. The Accounting Review 83 (4): 1083-1099.

Schatzberg, J., and D. Stevens. 2008. Public and private forms of opportunism within the organization: A joint examination of budget and effort behavior. Journal of Management Accounting Research 20 (1): 59-81.

Shields, J., and M. Shields. 1998. Antecedents of participative budgeting. Accounting, Organizations and Society 23 (1): 49-76.

Smith, V. 2010. Rationality in Economics: Constructivist and Ecological Forms. New York, NY: Cambridge University Press.

Stanca, L. 2010. How to be kind? Outcomes versus intentions as determinants of fairness. Economic Letters 106 (1): 19-21.

Stevens, D. 2002. The effect of reputation and ethics on budgetary slack. Journal of Management Accounting Research 14 (1): 153-171.

Stevens, D., and A. Thevaranjan. 2010. A moral solution to the moral hazard problem. Accounting, Organizations, and Society 35 (1): 125-139.

Takahashi, H., H. Takano, C. Camerer, T. Ideno, S. Okubo, H. Matsui, Y. Tamari, K. Takemura, R. Arakawa, F. Kodaka, M. Yamada, Y. Eguchi, T. Murai, Y. Okubo, M. Kato, H. Ito, and T. Suhara. 2012. Honesty mediates the relationship between serotonin and reaction to unfairness. Proceedings of the National Academy of Sciences 109 (11): 4281-4284.

Tayler, W., and R. Bloomfield. 2011. Norms, conformity, and controls. Journal of Accounting Research 49 (3): 753-790.

Young, M. 1985. Participative budgeting: The effects of risk-aversion and asymmetric information on budgetary slack. Journal of Accounting Research 23 (2): 829-842.

Zhang, Y. M. 2008. The effects of perceived fairness and communication on honesty and collusion in a multi-agent setting. The Accounting Review 83 (4): 1125-1146.

\section{APPENDIX $\mathbf{A}^{17}$ \\ Instructions for Factual Assertion/No Salary Authority/Private Information}

\section{Introduction}

Welcome and thank you for participating in this experiment. Your pay will depend on the decisions you make during the experiment. At the end of today's session, you will be paid in private and in cash. It is important that you remain silent and do not look at other people's work. If you have any questions, or need assistance of any kind, please raise your hand and an experimenter will come to you.

Before the first period begins, participants will be assigned as owners or managers. Half of the participants will be assigned as owners and half of the participants will be assigned as managers.

17 Adapted from Rankin et al. (2008). 
You remain as either an owner or manager for all periods. Each of you has an assigned subject number. At the beginning of each period, subjects are randomly paired by subject numbers. There will be 20 periods. Your experimental pay will be determined by as 20 times your earnings in one randomly drawn period. The period will be determined by the computer program at the conclusion of the experimental session.

\section{Overview}

Each period, each manager will be employed to implement a project for a fixed salary from each respective owner. Each period, the cost of implementing a project is randomly determined and revealed only to the manager. The cost is randomly drawn each period from the set of possible costs $(0,1,2, \ldots, 200)$. These numbers represent pennies (i.e., $200=\$ 2.00)$. Each number is equally likely to be drawn each period. The manager learns the cost. The owner NEVER LEARNS THE COST. If implemented, then the project yields revenue of 200 .

\section{Owners' Task}

At the beginning of the first period, the owner will learn what his or her initial level of funds will be, which does not vary between periods. Each period, the owner receives a cost report from the manager. The owner either rejects the project and gives the manager nothing, or accepts and funds the project and gets the 200 project revenue less the manager's reported cost, which is given to the manager.

\section{Managers' Task}

The manager will receive a fixed salary of 100 from the owner's initial funds each period regardless of the owner's decision. The manager observes the actual cost. After observing the actual cost, the manager reports a cost to the owner. The reported cost cannot be less than the actual cost. The owner either rejects the project and gives the manager nothing, or accepts the project and gets the 200 project revenue less the manager's reported cost. Since the project yields revenue of 200, the payoff to the owner is 200 minus the amount given to the manager if the project is implemented, and 0 otherwise. In addition, the owner will receive his or her initial funds each period less the salary of 100 paid to the manager each period, regardless of the owner's decision to implement the project. The payoff to the manager is the amount received from the owner minus the actual cost if the project is implemented, and 0 otherwise. In addition, the manager will receive the salary of 100 each period from the owner regardless of the owner's decision to implement the project.

\section{Summary and Sequence of Events}

The cost is randomly drawn each period from the set of possible costs $(0,1,2, \ldots, 200)$. Each number is equally likely to be drawn each period. The manager learns the actual cost and submits a cost report to the owner. The reported cost must be equal to or greater than the actual cost. The owner either rejects the project and gives the manager nothing, or accepts the project and gives the manager an amount equal to the manager's reported cost. At the beginning of each period, subjects are randomly paired by subject numbers. There will be 20 periods.

\section{Example}

If the actual cost is 50 , then the total profit is $200-50=150$. The manager can report any cost between 50 and 200 to the owner. If the manager reports 133, then the owner either (1) rejects the report and the manager and owner receive nothing, or (2) accepts the report, gives 133 to the 
manager, and the owner earns $200-133=67$ plus his initial funds less the 100 paid to the manager, and the manager earns $100+(133-50)=183$. That is, if the report is rejected, then the manager and owner receive nothing from the project, although the manager still receives his salary of 100 and the owner still receives his initial funds less the manager's salary of 100 . If the report is accepted, then the manager receives the salary of 100 plus the difference between the reported cost and actual cost $(133-50)$, and the owner receives the remainder of his initial funds (less the 100 paid to the manager) plus the profit above reported cost $(200-133)$. 
Copyright of Accounting Review is the property of American Accounting Association and its content may not be copied or emailed to multiple sites or posted to a listserv without the copyright holder's express written permission. However, users may print, download, or email articles for individual use. 